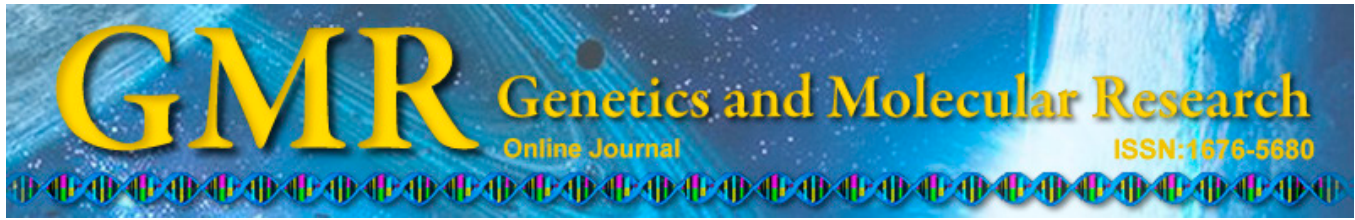

\title{
Effect of ultraviolet A exposure on transport of compatible organic osmolytes in human lens epithelial cells
}

\author{
D.Y. Wu ${ }^{1}$ and J.S. Zhang ${ }^{2}$ \\ ${ }^{1}$ Department of Ophthalmology, \\ The First Affiliated Hospital of Liaoning Medical University, Jinzhou, China \\ ${ }^{2}$ Department of Ophthalmology, \\ The Fourth Affiliated Hospital of China Medical University, Shenyang, China \\ Corresponding author: D.Y. Wu \\ E-mail: wudayang@gmail.com
}

Genet. Mol. Res. 14 (2): 5132-5140 (2015)

Received June 11, 2014

Accepted December 1, 2014

Published May 18, 2015

DOI http://dx.doi.org/10.4238/2015.May.18.3

\begin{abstract}
Compatible organic osmolytes, such as betaine, myoinositol, and taurine, are involved in antioxidant defense, protein stabilization, and stress responses. This osmolyte strategy requires the expression of specific osmolyte transporters such as betaine (BGT-1), myoinositol (SMIT), and taurine (TAUT). In contrast to the kidney, keratinocytes, and neural cells, few studies have examined osmolytes in human lens epithelial cells (HLECs). We examined the expression of mRNA specific for BGT-1, SMIT, and TAUT in HLECs. In comparison to normoosmotic ( $305 \mathrm{mOsM})$ controls, there was a 3-5-fold time-dependent reaction of BGT-1, SMIT, and TAUT mRNA levels in HLECs exposed to hyperosmotic stress (405 mOsM). Maximal responses were obtained for BGT-1, SMIT, and TAUT mRNA expression after 3, 24 and $9 \mathrm{~h}$ of hyperosmotic exposure, respectively. This expression was correlated with increased osmolyte uptake. In contrast, hypoosmotic (205 mOsM) stimulation led to a significant efflux of osmolytes. Exposure to ultraviolet A $(340-400 \mathrm{~nm})$ radiation
\end{abstract}


significantly stimulated osmolyte uptake. Increased osmolyte uptake was associated with upregulation of mRNA steady-state levels for osmolyte transporters in irradiated cells. These results demonstrate that ultraviolet A radiation leads to the accumulation of compatible organic osmolytes in HLECs as hyperosmotic pressure, which can maintain cellular environmental homeostasis.

Key words: Human lens epithelial cells; Organic osmolytes; Ultraviolet A

\section{INTRODUCTION}

Long-term exposure to ultraviolet radiation can cause cataract occurrence and development. Ultraviolet A (UVA, 320-400 nm) is a risk factor of cataract mainly because of lens absorption (Yam and Kwok, 2014). The mechanism of ultraviolet radiation in accelerating cataract development is caused by the generation of oxygen radicals, DNA fracture, and degeneration of lens protein kinase activation (Beshtawi et al., 2013). However, the effect of ultraviolet radiation on compatible organic osmolytes inside of the crystalline body is not well understood.

Compatible organic osmolytes, such as betaine, myoinositol, and taurine, are compounds that specifically accumulate in cells in response to hyperosmotic stress and are rapidly released from cells after hypoosmotic exposure (Kwon and Handler, 1995; Haussinger, 1996). These osmolytes are also involved in antioxidant defense, protein stabilization, and stress responses. Hypertonia can cause the acceleration of translation and synthesis of compatible organic osmolyte transporters, including BGT1, SMIT, and TAUT, which transport betaine, myoinositol, and taurine, respectively. A variety of tissues and organs for the osmolyte transport systems widely exist in the human body, including in the kidney, liver, and skin (Zhang et al., 1996; Burg et al., 1997; Warskulat et al., 1997a,b,c; Weik et al., 1998). However, there have been few reports regarding osmolyte transport systems in the human crystalline lens.

UV was previously found to increase intracellular reactive oxygen species, activation of protein kinase C, and p38 (Sarasin, 1999; Cheng et al., 2002), with reaction conditions similar to the hyperosmotic stress reaction. The final target of hypertonia and ultraviolet radiation is DNA, which leads to DNA fracture in cells (Heck et al., 2003). Numerous studies have found that high osmotic pressure can lead to the accumulation of compatible organic osmolytes inside cells, while UVA can cause a response that is similar to the hyperosmotic reaction (Thompson, 1988; Berry et al., 1994). Therefore, we examined whether UVA can cause similar accumulation of compatible organic osmolytes inside human lens epithelial cells (HLECs) as hyperosmotic pressure.

HLECs were found to maintain cellular environmental homeostasis. Furthermore, the taurine transport system is an important component of compatible organic osmolytes and resists DNA fracture caused by UVA in HLECs.

\section{MATERIAL AND METHODS}

\section{Cells}

HLECs were obtained from ScienCell Research Laboratories (Carlsbad, CA, USA) 
and cultured in Dulbecco's modified Eagle medium containing 10\% fetal bovine serum, 50 $\mathrm{U} / \mathrm{mL}$ penicillin, and $200 \mathrm{mg} / \mathrm{mL}$ streptomycin, and stored at $37^{\circ} \mathrm{C}$ under an atmosphere of $5 \% \mathrm{CO}_{2}$ in air. Osmolarity changes were achieved by varying the $\mathrm{NaCl}$ concentration in the medium, as osmotic regulation of mRNA steady state levels for TAUT, BGT-1, and SMIT and osmotic effects on osmolyte transport are independent of $\mathrm{Na}^{+}$and $\mathrm{Cl}^{-}$activity in all cell types examined, such as in kidney and liver cells as well as in human monocytes and macrophages.

\section{UV irradiation}

The medium was replaced with phosphate-buffered saline, and cells were exposed at a distance of $30 \mathrm{~cm}$ to UVA radiation from a UVA irradiation device (MUA-165, Beijing Huabin Photoelectric Instrument Co., Beijing, China) emitting over a range of 340-400 nm with a maximum of approximately $360 \mathrm{~nm}$. Dosimetry was conducted using a Waldmann UV meter type II (Herbert Waldmann GmbH \& Co., Villingen-Schwenningen, Germany) with a spectral sensitivity matching the main emission spectrum of approximately 350-400 nm. For shamirradiation, cells were not exposed to UVA radiation, but were otherwise treated identically.

\section{Real-time polymerase chain reaction $(\mathrm{PCR})$}

Total RNA from HLECs was isolated using a total RNA extraction kit (Omega BioTek, Norcross, GA, USA) and reverse-transcribed using a first-strand cDNA synthesis kit (D6110A; TAKARA, Shiga, Japan). Gene expression levels were measured by real-time SYBR Green PCR with the Gene Amp 5700 Sequence Detection System (Applied Biosystems, Foster City, CA, USA) according to manufacturer instructions. The primers used for PCR were 5'-AAAGCTGTGACAATGATGCCG-3' and 5'-CCAGTCCAAGCAAGAGAAGCA-3' for TAUT, 5'-AACAGTGCCACCAGCTTTGTG-3' and 5'-ACTCGGCCACTTCAGAAATGG-3' for $B G T-1,5^{\prime}$-TCAACCACATCATTCCCAACG-3' and 5'-TGCTGTCTTCAGATTTCCCGT-3' for SMIT, and 5'-AAGATGG-TCAAGGTCGCAAGC-3' and 5'-GGTCCTTTTCACCAGCA AGCT-3' for hypoxanthineguanine-phosphoribosyl-transferase as an internal standard. PCR conditions were: 1 cycle at $50^{\circ} \mathrm{C}$ for $2 \mathrm{~min}$ and $95^{\circ} \mathrm{C}$ for $10 \mathrm{~min}$, followed by 40 cycles at $95^{\circ} \mathrm{C}$ for $15 \mathrm{~s}$, and $60^{\circ} \mathrm{C}$ for $1 \mathrm{~min}$. The sample volume was $25 \mu \mathrm{L}$. After PCR, the specificity of the amplified DNA was assessed by recording the dissociation curve to distinguish the fluorescence peak corresponding to the amplicon from the peak due to primer-dimer formation.

\section{Uptake of betaine, myoinositol, and taurine}

Uptake of organic osmolytes was measured as described previously (Wu and Zhang, 2014). Briefly, HLECs were incubated for $16 \mathrm{~h}$ in serum-free culture medium at the indicated osmolarity. Thereafter, the medium was replaced with an identical volume of medium containing $100 \mathrm{mM}\left[{ }^{14} \mathrm{C}\right]$ betaine $(48.1 \mathrm{Ci} / \mathrm{mmol}),\left[{ }^{3} \mathrm{H}\right]$ taurine $(24 \mathrm{Ci} / \mathrm{mmol})$, or $\left[{ }^{3} \mathrm{H}\right]$ myoinositol $(22.3$ $\mathrm{Ci} / \mathrm{mmol}$, all purchased from Shanghai Company, Shanghai, China), and cells were incubated for the indicated periods of time. Cultures were rinsed 3 times with ice-cold stop solution containing $10 \mathrm{mM}$ Tris-HEPES, pH 7.4, $300 \mathrm{mM}$ mannitol, and $300 \mathrm{mM} \mathrm{NaCl}$. Cells were air-dried and lysed, and aliquots were subjected to liquid scintillation counting and protein determination (Bio-Rad Protein Assay, Bio-Rad, Hercules, CA, USA). 


\section{Efflux of betaine, myoinositol, and taurine}

HLECs were loaded with $10 \mathrm{mM}\left[{ }^{14} \mathrm{C}\right]$ betaine, $\left[{ }^{3} \mathrm{H}\right]$ taurine, or $\left[{ }^{3} \mathrm{H}\right]$ myoinositol in serum-free culture medium for $16 \mathrm{~h}$. Cells were rinsed twice with phosphate-buffered saline. After UVA irradiation, cells were incubated in betaine-, myoinositol-, and taurine-free normosmotic $(305 \mathrm{mOsM})$ or hypoosmotic $(205 \mathrm{mOsM})$ culture medium for the indicated periods of time. Medium and cell lysates were collected and radioactivity was measured by scintillation counting. Efflux of $\left[{ }^{14} \mathrm{C}\right]$ betaine, $\left[{ }^{3} \mathrm{H}\right]$ myoinositol, and $\left[{ }^{3} \mathrm{H}\right]$ taurine into the supernatant was expressed as the percentage of total radioactivity in cell lysates plus supernatants.

\section{Statistical analysis}

Statistical analysis was performed using the 2-tailed Student $t$-test. $\mathrm{P}$ values $<0.05$ were considered to be significant.

\section{RESULTS}

\section{Expression of BGT-1, SMIT, and TAUT mRNA in HLECs}

Under normoosmotic (305 mOsM) conditions, real-time reverse transcription-PCR analysis revealed that HLECs expressed mRNA specific for BGT-1, SMIT, and TAUT $(0.2 \pm 0.1$, $3.9 \pm 0.3$, and $0.1 \pm 0.2 \mathrm{mRNA}$ copies/hypoxanthineguanine-phosphoribosyl-transferase mRNA copy). The levels of BGT-1, SMIT and TAUT mRNA were increased by 3-5-fold when HLECs were exposed to hyperosmotic stress (405 mOsM). Maximum BGT-1, SMIT, and TAUT mRNA expression was observed after 3, 24, and 9h of hyperosmotic exposure, respectively (Figure 1).

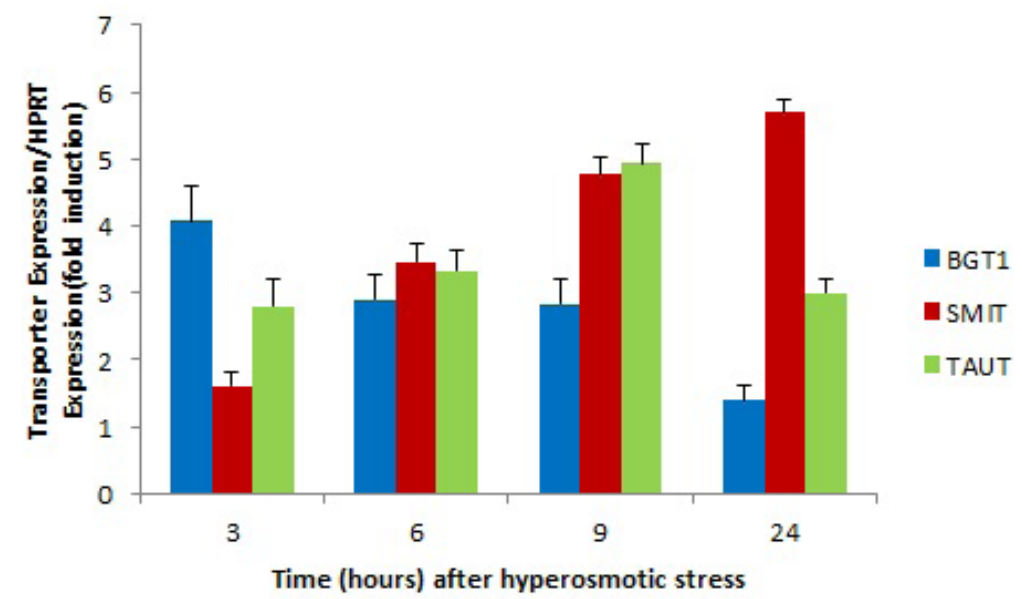

Figure 1. Reaction of BGT-1, SMIT, and TAUT mRNA in human lens epithelial cells (HLECs) after hyperosmotic exposure as detected by real-time reverse transcription-polymerase chain reaction. Hyperosmotic (405 mOsM) exposure of HLECs for the indicated time periods. Osmolarity was changed by adding $\mathrm{NaCl}$. Results are given as the fold reaction based on HPRT (housekeeping) gene expression in stimulated vs unstimulated cells as a control. Gene expression under control (normoosmotic conditions in sham-irradiated cells) condition was measured at all indicated time points and arbitrarily set as 1 . Data are from 3 independent experiments. 


\section{Organic osmolyte transport in HLECs}

Measuring of the uptake of radiolabeled osmolytes indicated the functional significance of hyperosmotic stress-induced osmolyte transporter mRNA expression in HLECs. Under normoosmotic (305 mOsM) conditions, HLECs took up betaine, myoinositol, and taurine at low levels (Table 1). Taurine uptake was 3.6- and 2.9-fold higher than uptake of betaine and myoinositol over $2 \mathrm{~h}$. Culture of HLECs in osmolyte-free, normoosmotic versus hyperosmotic media for $16 \mathrm{~h}$ and subsequent exposure for $2 \mathrm{~h}$ to media containing $100 \mathrm{mM}$ betaine, myoinositol, or taurine led to a dramatic increase in osmolyte uptake in hyperosmotically stressed cells, with 2-, 1.7-, and 2.3-fold increases for betaine, myoinositol, and taurine, respectively. In addition, because of the moderate accumulation of osmolytes into cells, the 2-h uptake values do not reflect intracellular steady-state levels, but represent roughly initial uptake rates and thereby reflect transporter activity.

Table 1. Organic osmolyte transport in human lens epithelial cells.

\begin{tabular}{llcc}
\hline Osmolyte Test conditions & \multicolumn{3}{c}{ Osmolyte uptake (nmol/mg protein) } \\
\cline { 2 - 4 } & Betaine & Myoinositol & Taurine \\
\hline $305 \mathrm{mOsM}+$ sham-irradiation & $1.1 \pm 0.4$ & $1.4 \pm 0.1$ & $4.0 \pm 0.1$ \\
$405 \mathrm{mOsM}+$ sham-irradiation & $2.3 \pm 0.1^{*}$ & $2.4 \pm 0.3^{*}$ & $9.0 \pm 2.0^{*}$ \\
$305 \mathrm{mOsM}+10 \mathrm{~J} / \mathrm{cm}^{2}$ UVA & $1.3 \pm 0.2$ & $1.6 \pm 0.4$ & $5.4 \pm 0.3$ \\
$305 \mathrm{mOsM}+30 \mathrm{~J} / \mathrm{cm}^{2}$ UVA & $2.3 \pm 0.3^{*}$ & $2.8 \pm 0.2^{*}$ & $7.6 \pm 0.1^{*}$ \\
\hline
\end{tabular}

Cells were ultraviolet-irradiated or sham-irradiated as indicated and then incubated for $16 \mathrm{~h}$ in normoosmotic ( $305 \mathrm{mOsM})$ or hyperosmotic medium (405 mOsM). Osmolarity was changed by adding $50 \mathrm{mM} \mathrm{NaCl}$. Uptake of $100 \mathrm{mM}$ taurine, betaine, or myoinositol was assessed for $2 \mathrm{~h}$ in medium with the same osmolarity. Data are reported as means \pm standard error of the mean $(\mathrm{N}=3)$. *Significantly different from the control condition ( $305 \mathrm{mOsM}$, sham-irradiated), $\mathrm{P}<0.05$.

\section{Efflux of osmolytes after hypoosmotic exposure}

HLECs were allowed to accumulate osmolytes (added at a concentration of $10 \mathrm{mM}$ ) for $16 \mathrm{~h}$. Next, cells were washed twice and incubated in normoosmotic (305 mOsM) or hypoosmotic (205 mOsM) buffer for between $5 \mathrm{~min}$ and $1 \mathrm{~h}$. This hypoosmotic stimulation induced a significant efflux of osmolytes (Table 2). The release of betaine in isoosmotic medium was only $31 \%$ after $1 \mathrm{~h}$, whereas in hypoosmotic medium, this value was $36 \%$ after 5 min and $66 \%$ after $1 \mathrm{~h}$. Efflux of myoinositol and taurine in isoosmotic medium was 15 and $26 \%$ after $1 \mathrm{~h}$, but was 32 and $80 \%$ in hypoosmotic medium, respectively (Table 2 ).

\begin{tabular}{|c|c|c|c|c|c|c|}
\hline \multirow[t]{3}{*}{ Test conditions } & \multicolumn{6}{|c|}{ Osmolyte efflux (\% of total radioactivity) } \\
\hline & \multicolumn{2}{|c|}{ Betaine } & \multicolumn{2}{|c|}{ Myoinositol } & \multicolumn{2}{|c|}{ Taurine } \\
\hline & $5 \mathrm{~min}$ & $60 \mathrm{~min}$ & $5 \mathrm{~min}$ & $60 \mathrm{~min}$ & $5 \mathrm{~min}$ & $60 \mathrm{~min}$ \\
\hline $\begin{array}{l}305 \mathrm{mOsM}+\text { sham-irradiation } \\
205 \mathrm{mOsM}+\text { sham-irradiation } \\
305 \mathrm{mOsM}+100 \mathrm{~mJ} / \mathrm{cm}^{2} \mathrm{UVA}\end{array}$ & $\begin{array}{l}17 \pm 3 \\
36 \pm 4 * \\
22 \pm 2\end{array}$ & $\begin{array}{l}31 \pm 1 \\
66 \pm 6^{*} \\
34 \pm 3\end{array}$ & $\begin{array}{l}13 \pm 2 \\
24 \pm 3^{*} \\
16 \pm 3\end{array}$ & $\begin{array}{l}15 \pm 2 \\
32 \pm 3^{*} \\
18 \pm 3\end{array}$ & $\begin{array}{l}16 \pm 1 \\
50 \pm 3^{*} \\
19 \pm 2\end{array}$ & $\begin{array}{l}26 \pm 4 \\
80 \pm 6^{*} \\
29 \pm 3\end{array}$ \\
\hline \multicolumn{7}{|c|}{$\begin{array}{l}\text { Cells were allowed to accumulate betaine, myoinositol, or taurine (added at a concentration of } 10 \mathrm{mM} \text { ) for } 16 \mathrm{~h} \text {, } \\
\text { washed twice, UVA- or sham-irradiated as indicated, and exposed to osmolyte-free normoosmotic ( } 305 \mathrm{mOsM}) \text { or } \\
\text { hypoosmotic ( } 205 \mathrm{mOsM}) \text { Krebs-Henseleit buffer. Taurine, betaine, and myoinositol appearance in the supernatan } \\
\text { was detected and expressed as the percentage of total radioactivity (contained in cells plus supernatant). Data are } \\
\text { reported as the means } \pm \text { standard error of the mean and are from } 3 \text { separate experiments. *Significantly different } \\
\text { from the control condition ( } 305 \mathrm{mOsM} \text {, sham-irradiated), } \mathrm{P}<0.01 \text {. }\end{array}$} \\
\hline
\end{tabular}




\section{UVA radiation induced alterations in $B G T-1, S M I T$, and $T A U T$ mRNA levels and increased osmolyte uptake in HLECs}

In this study, a UVA irradiation device was used, which primarily emitted in the longwave UVA range 340-400 $\mathrm{nm}$ with an emission maximum of approximately $312 \mathrm{~nm}$. UVA radiation $\left(30 \mathrm{~mJ} / \mathrm{cm}^{2}\right)$ significantly stimulated myoinositol and taurine uptake in HLECs; however, there was no significant difference after $10 \mathrm{~mJ} / \mathrm{cm}^{2}$ radiation (Table 1). In contrast to hypoosmotic exposure, UVA radiation did not affect osmolyte efflux from HLECs (Table 2). Modulation of osmolyte uptake and osmolyte transporter expression was observed after UVA irradiation. Accordingly, UVA radiation resulted in upregulation of all transporters tested (Figure 2). Expression of BGT-1 mRNA was induced 4-, 4.5-, and 5-fold at 6, 12, and $24 \mathrm{~h}$, respectively, after irradiation with $30 \mathrm{~J} / \mathrm{cm}^{2}$ UVA. SMIT mRNA expression increased by 3 -fold at 10 and $30 \mathrm{~J} / \mathrm{cm}^{2}$ after $24 \mathrm{~h}$. TAUT mRNA expression showed a concentration-dependent increase at both time points. Upregulation of osmolyte transporter mRNA expression was associated with significantly increased uptake of the respective osmolytes in UVA-irradiated HLECs (Table 1).

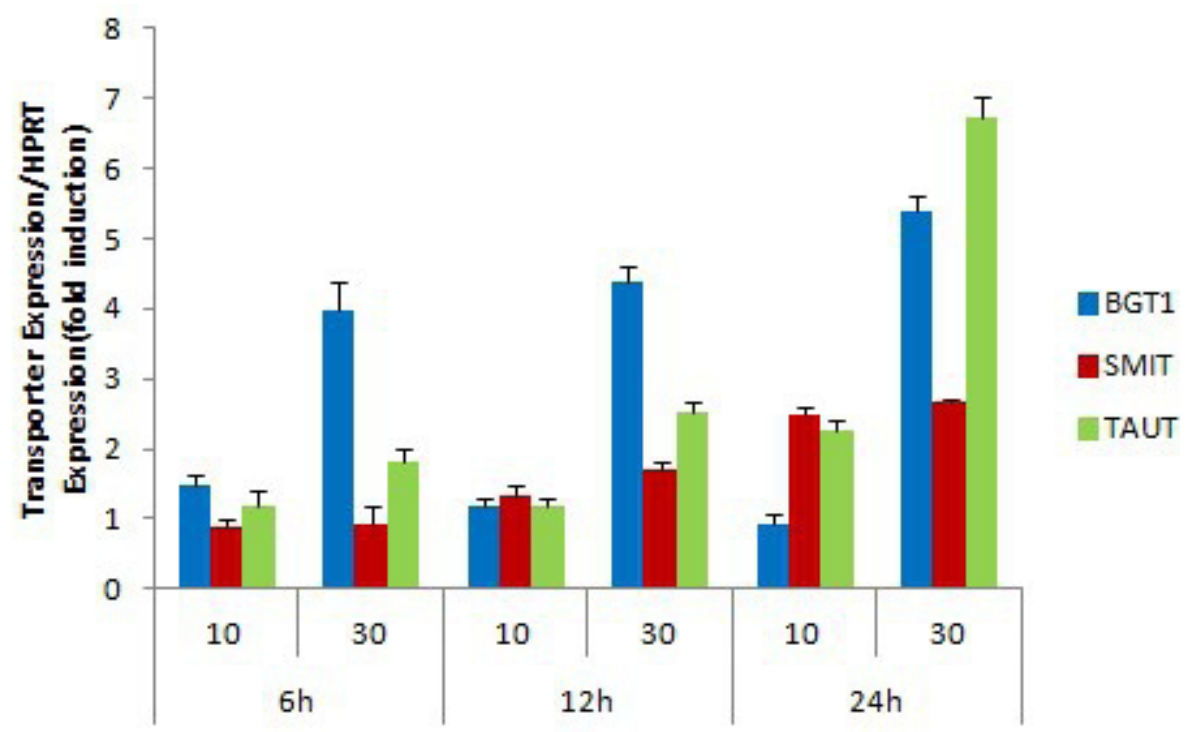

Figure 2. Reaction of BGT-1, SMIT, and TAUT mRNA in human lens epithelial cells (HLECs) after ultraviolet A (UVA) radiation as detected by real-time reverse transcription-polymerase chain reaction. HLECs were exposed to 2 doses of UVA radiation $\left(10\right.$ or $\left.30 \mathrm{~J} / \mathrm{cm}^{2}\right)$ and detected at 6,12 , and $24 \mathrm{~h}$ after UVA treatment.

\section{DISCUSSION}

We found that betaine, myoinositol, and taurine were compatible organic osmolytes in HLECs. Our results showed that i) HLECs expressed mRNA specific for BGT-1, SMIT, and TAUT, and this expression was upregulated upon hyperosmotic exposure; ii) mRNA expression of osmolyte transporters was associated with uptake of the respective osmolytes, and osmolyte uptake was significantly increased in these cells under hyperosmotic stress; and iii) 
incubation of HLECs in hypoosmotic medium led to rapid efflux of betaine, myoinositol, and taurine from cells.

Compatible organic osmolytes are compounds that specifically accumulate in cells in response to hyperosmotic stress. Organic osmolytes are non-perturbing solutes that do not interfere with protein function, even when present at high intracellular concentrations (Burg et al., 1997). Betaine, myoinositol, and taurine were previously identified as osmolytes in the brain, kidney, and liver and interfere with cell volume regulation and cell function (Haussinger, 1998). Compatible organic osmolytes are important not only for cell volume homeostasis but also for cell protection, such as against oxidative stress (Yancey et al., 1982; Huxtable, 1992). They can stabilize native protein structures and protein function (Welch and Brown 1996), and thus betaine and taurine can protect cells in vitro against various types of injury (Wettstein and Haussinger, 2000; Alfieri et al., 2002). Altered osmolyte content has been described for important diseases (vom Dahl et al., 2000; Hansen, 2001). Thus, it appears likely that similarly to the kidney, liver, and neural cells, HLECs possess an osmolyte strategy that may be important for maintaining cell volume homeostasis and reflect part of their stress response towards environmental noxae such as ultraviolet radiation.

A major source of oxidative stress is ultraviolet radiation, and cellular oxidative stress may result in cell hydration changes (Peus and Pittelkow, 2001). Because ultraviolet radiation and osmotic stimulation induce similar signaling events, the influence of UVA on osmolyte transport was investigated in HLECs in the present study. It should be noted that at wavelengths above $300 \mathrm{~nm}$, the generation of oxidative stress becomes increasingly important because of the direct formation of DNA photoproducts (Kochevar, 1985; Stege et al., 2000), and the direct damage to lens homeostasis (Wu et al., 2011).

In this context, taurine was the most affected osmolyte under the stimulation conditions tested, and this osmolyte is therefore most likely to be related to UVA responses of HLECs. Increased osmolyte uptake after UVA irradiation in HLECs was associated with upregulation of osmolyte transporter mRNA expression. This indicates that the UVA-induced increase in osmolyte uptake most likely reflected an active process such as increased synthesis of transporter proteins rather than short-term activation of pre-existing transporters. Similarly, long-term induction of osmolyte transporter expression and osmolyte uptake has been reported for hyperosmotically stressed rat liver cells (Weik et al., 1998) and human monocytes and macrophages (Denkert et al., 1998) as well as ultraviolet-exposed keratinocytes (Thompson, 1998). It was recently shown that taurine improves epidermal barrier properties and may play a role in barrier homeostasis (Anderheggen et al., 2006). However, the mechanical effect of the UVA compromising the membrane followed by influx from a hyperosmolarity environment cannot be completely ruled out. Because taurine and betaine have antioxidative activities (Mehta et al., 2002; Patrick, 2002), the increased osmolyte uptake by UVA-irradiated HLECs may not only be important in cell volume homeostasis but also may be part of their defense strategy against UVA-induced disease such as cataract.

In conclusion, HLECs possess an osmolyte strategy with induction of osmolyte uptake by UVA. However, the influence of organic osmolytes is unknown. Thus, future in vivo studies should examine whether this osmolyte, through this or additional functions, is capable of protecting HLECs against ultraviolet radiation-induced biological effects. Studies employing TAUT knockout mice (Rockel et al., 2007) will be useful for testing taurine functions and their effects on the human lens. 


\section{REFERENCES}

Alfieri RR, Cavazzoni A, Petronini PG, Bonelli MA, et al. (2002). Compatible osmolytes modulate the response of porcine endothelial cells to hypertonicity and protect them from apoptosis. J. Physiol. 540: 499-508.

Anderheggen B, Jassoy C, Waldmann-Laue M, Förster T, et al. (2006). Taurine improves epidermal barrier properties stressed by surfactants-a role for osmolytes in barrier homeostasis. J. Cosmet. Sci. 57: 1-10.

Berry GT, Prantner JE, States B and Yandrasitz JR (1994). The effect of glucose and galactose toxicity on myo-inositol transport and metabolism in human skin fibroblasts in culture. Pediatr. Res. 35: 141-147.

Beshtawi IM, O'Donnell C and Radhakrishnan H (2013). Biomechanical properties of corneal tissue after ultraviolet-Ariboflavin crosslinking. J. Cataract Refract. Surg. 39: 451-462.

Burg MB, Kwon ED and Kultz D (1997). Regulation of gene expression by hypertonicity. Annu. Rev. Physiol. 59: 437-455.

Cheng H, Kartenbeck J, Kabsch K, Mao X, et al. (2002). Stress kinase p38 mediates EGFR transactivation by hyperosmolar concentrations of sorbitol. J. Cell. Physiol. 192: 234-243.

Denkert C, Warskulat U, Hensel F and Häussinger D (1998). Osmolyte strategy in human monocytes and macrophages: involvement of p38MAPK in hyperosmotic induction of betaine and myoinositol transporters. Arch. Biochem. Biophys. 354: 172-180.

Hansen SH (2001). The role of taurine in diabetes and the development of diabetic complications. Diabetes Metab. Res. Rev. 17: 330-346.

Haussinger D (1996). The role of cellular hydration in the regulation of cell function. Biochem. J. 313: 697-710.

Haussinger D (1998). Osmoregulation of liver cell function: signalling, osmolytes and cell heterogeneity. Contrib. Nephrol. 123: 185-204.

Heck DE, Vetrano AM, Mariano TM and Laskin JD (2003). UVB light stimulates production of reactive oxygen species: unexpected role for catalase. J. Biol. Chem. 278: 22432-22436.

Huxtable RJ (1992). Physiological actions of taurine. Physiol. Rev. 72: 101-163.

Kochevar IE (1985). Action spectrum and mechanisms of UV radiation-induced injury in lupus erythematosus. J. Invest. Dermatol. 85: 140s-143s.

Kwon HM and Handler JS (1995). Cell volume regulated transporters of compatible osmolytes. Curr. Opin. Cell Biol. 7 : 465-471.

Mehta K, Van Thiel DH, Shah N and Mobarhan S (2002). Nonalcoholic fatty liver disease: pathogenesis and the role of antioxidants. Nutr. Rev. 60: 289-293.

Patrick L (2002). Nonalcoholic fatty liver disease: relationship to insulin sensitivity and oxidative stress. Treatment approaches using vitamin E, magnesium, and betaine. Altern. Med. Rev. 7: 276-291.

Peus D and Pittelkow MR (2001). Reactive oxygen species as mediators of UVB-induced mitogen-activated protein kinase activation in keratinocytes. Curr. Probl. Dermatol. 29: 114-127.

Rockel N, Esser C, Grether-Beck S, Warskulat U, et al. (2007). The osmolyte taurine protects against ultraviolet B radiation-induced immunosuppression. J. Immunol. 179: 3604-3612.

Sarasin A (1999). The molecular pathways of ultraviolet-induced carcinogenesis. Mutat. Res. 428: 5-10.

Stege H, Roza L, Vink AA, Grewe M, et al. (2000). Enzyme plus light therapy to repair DNA damage in ultraviolet-Birradiated human skin. Proc. Natl. Acad. Sci. U. S. A. 97: 1790-1795.

Thompson GN (1998). Taurine uptake by normal and cystic fibrosis fibroblasts. Biochem. Cell. Biol. 66: 702-706.

vom Dahl S, Monnighoff I and Haussinger D (2000). Decrease of plasma taurine in Gaucher disease and its sustained correction during enzyme replacement therapy. Amino Acids 19: 585-592.

Warskulat U, Weik C and Haussinger D (1997a). myo-Inositol is an osmolyte in rat liver macrophages (Kupffer cells) but not in RAW 264.7 mouse macrophages. Biochem. J. 326: 289-295.

Warskulat U, Wettstein M and Haussinger D (1997b). Osmoregulated taurine transport in H4IIE hepatoma cells and perfused rat liver. Biochem. J. 321: 683-690.

Warskulat U, Zhang F and Haussinger D (1997c). Taurine is an osmolyte in rat liver macrophages (Kupffer cells). $J$. Hepatol. 26: 1340-1347.

Weik C, Warskulat U, Bode J, Peters-Regehr T, et al. (1998). Compatible organic osmolytes in rat liver sinusoidal endothelial cells. Hepatology 27: 569-575.

Welch WJ and Brown CR (1996). Influence of molecular and chemical chaperones on protein folding. Cell Stress Chaperones 1: 109-115.

Wettstein M and Haussinger D (2000). Taurine attenuates cold ischemia-reoxygenation injury in rat liver. Transplantation 69: 2290-2296.

Wu D and Zhang J (2014). Taurine inhibits interleukin-6 expression and release induced by ultraviolet B exposure to 
human retinal pigment epithelium cells. Cutan. Ocul. Toxicol. 2014: 1-6.

Wu D, Zhao J, Wu D and Zhang J (2011). Ultraviolet A exposure induces reversible disruption of gap junction intercellular communication in lens epithelial cells. Int. J. Mol. Med. 28: 239-245.

Yam JC and Kwok AK (2014). Ultraviolet light and ocular diseases. Int. Ophthalmol. 34: 383-400.

Yancey PH, Clark ME, Hand SC, Bowlus RD, et al. (1982). Living with water stress: evolution of osmolyte systems. Science 217: 1214-1222.

Zhang F, Warskulat U, Wettstein M and Häussinger D (1996). Identification of betaine as an osmolyte in rat liver macrophages (Kupffer cells). Gastroenterology 110: 1543-1552. 